\title{
Oxidation of Homogentisic Acid by Cell-free Extracts of a Vibrio
}

\author{
By P. J. CHAPMAN* AND S. DAGLEY \\ Department of Biochemistry, University of Leeds
}

(Received 16 August 1961)

\section{SUMMARY}

Acetoacetic acid is a product of degradation of homogentisic acid by cellfree extracts of a vibrio grown with phenylacetic acid as sole carbon source. 4-Maleylacetoacetate was identified as a reaction intermediate; reduced glutathione was a cofactor for this enzymic degradation. These reactions are similar to those catalysed by enzymes of rat liver.

\section{INTRODUCTION}

Homogentisic acid is an intermediate in the bacterial oxidation of tyrosine (Suda \& Takeda, 1950; Jones, Smith \& Evans, 1952), phenylalanine (Dagley, Fewster \& Happold, 1953) and phenylacetic acid (Dagley et al. 1953; Kunita, 1955a). In animal liver 4-maleylacetoacetate is first formed from homogentisate by the singlestep addition of $\mathrm{O}_{2}$, catalysed by homogentisate oxidase; it then isomerizes to 4fumarylacetoacetate. This reaction, which requires reduced glutathione (GSH), is followed by hydrolysis of 4-fumarylacetoacetate to fumarate and acetoacetate (Knox \& Edwards, 1955; Knox, 1960). Many alternative routes exist for the oxidation of aromatic compounds by bacteria (Dagley, Evans \& Ribbons, 1960) and further evidence was therefore required before it could be assumed that the same reactions occur when bacteria oxidized homogentisic acid or its precursors. This evidence is now presented.

\section{ME'THODS}

The organism used was the vibrio $\mathrm{O} 1$ (National Collection of Industrial Bacteria, Torry Research Station, Aberdeen; NCIB 8250) originally isolated by Happold \& Key (1932). Batches of organisms were grown at $30^{\circ}$ with forced aeration in a medium adjusted with $\mathrm{NaOH}$ to $\mathrm{pH} 7 \cdot 2$ and containing (g./l.): $\mathrm{KH}_{2} \mathrm{PO}_{4}, 2$; $\left(\mathrm{NH}_{4}\right)_{2} \mathrm{SO}_{4}, 1 ; \mathrm{MgSO}_{4} .7 \mathrm{H}_{2} \mathrm{O}, 0 \cdot 4$; phenylacetic acid, 0.7. Organisms were transferred from a slope to $25 \mathrm{ml}$. of this medium aerated at $30^{\circ}$ in a boiling tube $(6 \mathrm{in} . \times 1 \mathrm{in}$.$) and after 24 \mathrm{hr}$. the whole of the fully-grown culture was used to inoculate 11 . of medium aerated in a 21 . flask. The resulting culture was used as inoculum for $8 \mathrm{l}$. of medium in a 10 l. flask into which passed a glass tube fitted with an aquarium aerator stone. From $9 \mathrm{l}$. of this culture about $6 \mathrm{~g}$. (wet weight) of organism was obtained after incubation overnight at $30^{\circ}$. All buffer solutions contained 2 g. of $\mathrm{KH}_{2} \mathrm{PO}_{4} /$ l, brought to $\mathrm{pH} 7 \cdot 2$ with $\mathrm{NaOH}$. Cell-free extracts were prepared from organisms disrupted at $-14^{\circ}$ without abrasive in the bacterial press

* Present address: Biochemistry Division, Chemistry Department, University of Illinois, Urbana, U.S.A. 
of Hughes (1951), extracted with buffer and centrifuged at $10,500 \mathrm{~g}$ for $45 \mathrm{~min}$. to remove insoluble material. Uptake of $\mathrm{O}_{2}$ and evolution of $\mathrm{CO}_{2}$ were followed by the conventional manometric procedures (Umbreit, Burris \& Stauffer, 1949). Acetoacetic acid was determined by coupling with diazotized $p$-nitroaniline to give a coloured substituted formazan. This reaction is quantitative when carried out according to Walker (1954) and is specific for compounds containing a reactive methylene group; thus, pyruvic acid and many other metabolites do not react. Acetoacetic acid was prepared from freshly-distilled ethyl acetoacetate by the method of Krueger (1952). $m$-Hydroxyphenylacetic acid was prepared according to King \& McMillan (1946). Other materials were commercially available. The protein concentrations of cell-free extracts were determined by the method of Sols (1947) with reference to a calibration curve made by using crystalline bovine serum albumin. Concentrations of maleylacetoacetate and fumarylacetoacetate were calculated from measurements of optical densities at $330 \mathrm{~m} \mu$, one part of the given solution being brought to $\mathrm{pH} 1$ and the other to $\mathrm{pH} 13$ by addition of $\mathrm{HCl}$ and $\mathrm{NaOH}$, respectively. Knox \& Edwards (1955) used the known molar extinction coefficients at these two $\mathrm{pH}$ values to derive formulae which give the amounts of maleylacetoacetate and fumarylacetoacetate in mixtures of the two. Absorption spectra were read in a Unicam SP 500 spectrophotometer using silica cells of $1 \mathrm{~cm}$. light path.

\section{RESULTS}

\section{Oxidation of hon ogentisate by crude cell extracts}

Cell-free extracts of the vibrio grown with phenylacetic acid catalysed the rapid oxidation of homogentisic acid (Fig. $1 a$ ) with an uptake of nearly 1.5 mole $\mathrm{O}_{2} /$ mole homogentisate. Phenylacetic, homoprotocatechuic (3:4-dihydroxyphenylacetic) and mono-hydroxyphenylacetic acids were not oxidized. When uptake of oxygen had ceased the flask contents were cooled in ice, protein precipitated by addition of 0.2 volume of $20 \%(\mathrm{w} / \mathrm{v})$ metaphosphoric acid and the precipitate removed by centrifugation and discarded. The contents of the flask containing cell extract but no substrate were treated similarly and served as a control. No reaction was given for homogentisic acid (Neuberger, 1947) but its conversion to a $\beta$-oxoacid was shown by a strong positive Rothera reaction. (Rothera, 1908) and by the immediate evolution of $\mathrm{CO}_{2}$ on addition of aniline citrate to solutions in respirometer flasks (Umbreit et al. 1949). Similar enzyme preparations from rat liver convert homogentisate to acetoacetate (Knox \& Edwards, 1955). When samples of deproteinized reaction mixtures were treated according to the procedure of Walker (1954) the spectrum of the compound formed was very similar to that given by acetoacetic acid similarly treated (Fig. 2). The quantity of acetoacetate agreed with that given by aniline citrate decarboxylation and was equivalent to the homogentisate which disappeared (Table 1).

\section{Oxidation of homogentisate by dialysed cell-free extracts}

When crude cell extracts were dialysed for $6 \mathrm{hr}$. at $5^{\circ}$ against phosphate buffer the oxidation of homogentisate was catalysed only when ferrous ions were added and the total oxygen uptake was also decreased but was still greater than 1 mole $\mathrm{O}_{2} /$ mole substrate (Fig. $1 b$ ). After reaction, solutions were deproteinized with 
metaphosphoric acid, neutralized with $2 \mathrm{~N}-\mathrm{NaOH}$ and equal volumes diluted with distilled water, $3 \mathrm{~N}-\mathrm{H}_{2} \mathrm{SO}_{4}$ and $5 \mathrm{~N}-\mathrm{NaOH}$ for determination of absorption spectra at $\mathrm{pH}$ values of 7,1 , and 13 respectively (Fig. 3). The spectra are similar to those of maleylacetoacetate (Knox \& Edwards, 1955) with a maximum at $330 \mathrm{~m} \mu$ at $\mathrm{pH} 13$, abolished at $\mathrm{pH}$ 1. From the published extinction coefficients, about $1.0 \mu$ mole

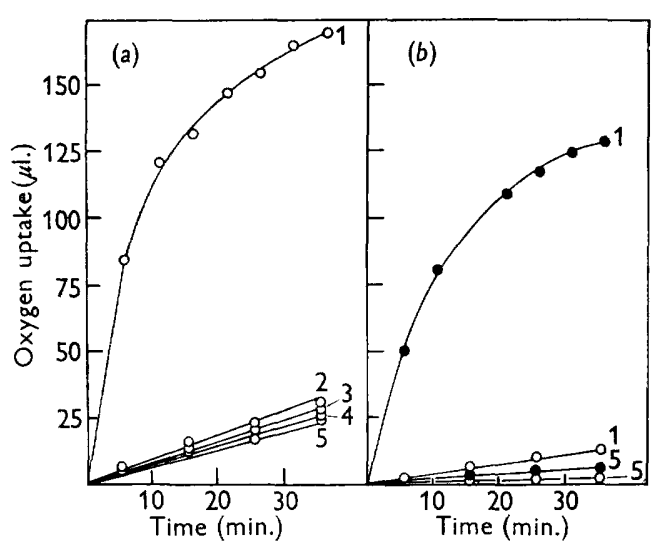

Fig. 1

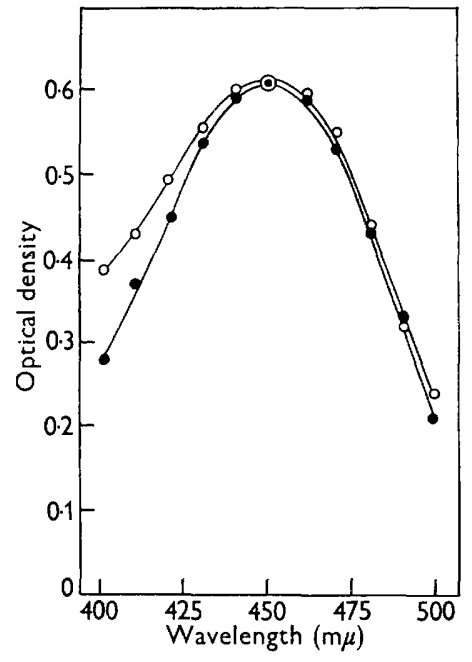

Fig. 2

Fig. 1. Oxidation of homogentisic acid by extracts of vibrio $\mathrm{O} 1$ grown with phenylacetic acid as carbon source. The extract used was either $(a)$ untreated or $(b)$ dialysed for $6 \mathrm{hr}$. Warburg flasks at $30^{\circ}$ contained extract (equiv. $20 \mathrm{mg}$. protein) and buffer ( $\mathrm{pH} 7 \cdot 2$ ) to a total volume of $3 \mathrm{ml}$. and $\mathrm{KOH}$ in centre well. The substrates ( $5 \mu \mathrm{mole})$ added from side bulbs are shown by numbers; 1 , homogentisate; 2 , homoprotocatechuate; 3 , phenylacetate; 4, $o$-, $m$ - and $p$-phenylacetate; extract, but no substrate was added in 5 . In Fig. $1 b$, mM-FeSO 4 was added to mixtures shown by blacked-in circles.

Fig. 2. Absorption spectra of solutions in ethyl acetate after reaction with diazotized $p$ nitroaniline. Acetoacetate was coupled under standard conditions (Walker, 1954) and the reaction product extracted completely into $4 \mathrm{ml}$. ethyl acetate. Product of enzymic oxidation of homogentisate by untreated vibrio $O 1$ extract $\left(\mathrm{O}_{-} \mathrm{O}\right) ; 8.5 \mu \mathrm{g}$. authentic acetoacetic acid

\section{Table 1. Formation of reaction intermediates in the enzymic oxidation of homogentisate}

Reactions took place in Warburg flasks at $30^{\circ}$ containing $5 \mu$ mole homogentisate, cell-free extract of vibrio $\mathrm{O} 1$ (20 $\mathrm{mg}$. protein) and buffer, $\mathrm{pH} \mathrm{7.2,} \mathrm{to} \mathrm{a} \mathrm{total} \mathrm{volume} \mathrm{of}$ $3 \mathrm{ml}$. When $\mathrm{O}_{2}$-uptake ceased, mixtures were deproteinized by addition of $0.3 \mathrm{ml}$. $20 \%(w / v)$ metaphosphoric acid. The amounts of acetoacetate (by coupling with diazotized $p$-nitroaniline) and of 4-maleylacetoacetate and 4-fumarylacetoacetate (from extinctions at $330 \mathrm{~m} \mu$ ) were then determined.

\section{Expt. Enzyme}

1 Untreated

2 Dialysed for $6 \mathrm{hr}$.; $\mathrm{mm}-\mathrm{FeSO}_{4}$ added

3 Dialysed for $12 \mathrm{hr}$.; $\mathrm{mm}_{-}-\mathrm{FeSO}_{4}$ added

4 Dialysed for $12 \mathrm{hr}$.; $\mathrm{mm}^{-F_{e S O}}+0.3 \mathrm{~mm}$ GSH added

$\begin{array}{ccc}\begin{array}{c}\text { 4-Maleylaceto- } \\ \text { acetate }(\mu \text { mole })\end{array} & \begin{array}{c}\text { 4-Fumarylaceto- } \\ \text { acetate }(\mu \text { mole })\end{array} & \begin{array}{c}\text { Acetoacetate } \\ (\mu \text { mole })\end{array} \\ 0 & 0 & 4 \cdot 80 \\ 1 \cdot 02 & 0 \cdot 18 & - \\ 2 \cdot 63 & 0 \cdot 32 & - \\ 0 & 0 & 4.85\end{array}$


maleylacetoacetate and $0 \cdot 2 \mu$ mole fumarylacetoacetate accumulated; the latter absorbs ultraviolet radiation stron trum at $\mathrm{pH} 1$ in Fig. 3. In a simils r experiment an extract was dialysed for $\mathbf{1 2} \mathrm{hr}$. and the yield of maleylacetoacetat a was more than doubled. When reduced glutathione was added, no ultraviolet absorbing compound accumulated and homogentisate was converted almost quintitatively to acetoacetate (Table 1).

The identity of the compound formed from homogentisate by the bacterial extract was confirmed by comparing its reaction with $o$-phenylenediamine to that of maleylacetoacetate obtained by means of the liver preparation. To each $2 \mathrm{ml}$. of a solution containing about $5 \mu$ mole maleylacetoacetate were added $6 \mathrm{ml}$. of a freshly made solution of $200 \mathrm{mg}$. $o$-phenylenediamine dissolved in $25 \mathrm{ml}$. of the following

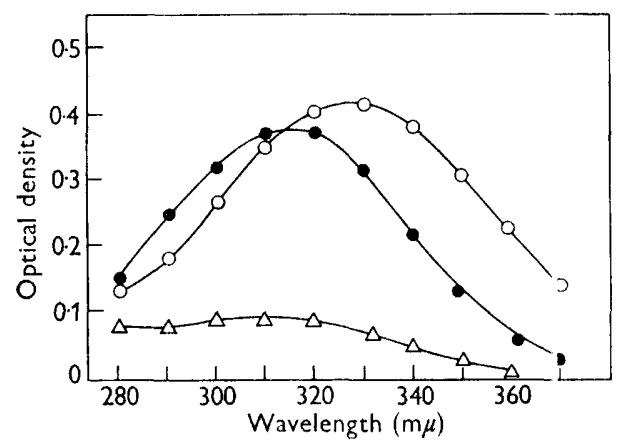

Fig. 3

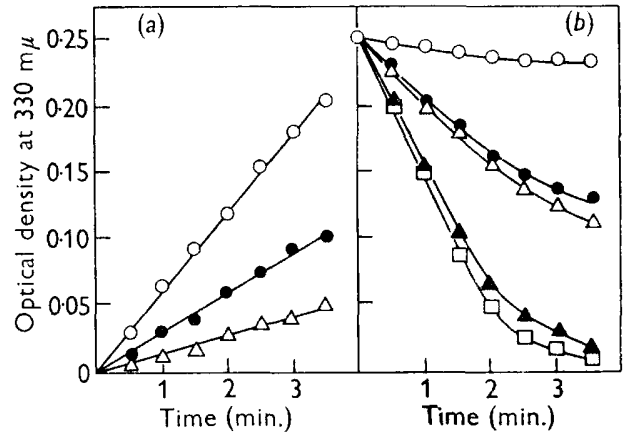

Fig. 4

Fig. 3. Absorption spectra of the product of oxidation of homogentisate by a dialysed vibrio 01 cell extract. Spectra were ead at: $\mathrm{pH} 7(\bullet-\bullet), \mathrm{pH} 1(\triangle-\triangle), \mathrm{pH} 13(0-\bigcirc)$.

Fig. 4. Formation ( $a$ ), and breakdown $(b)$, of maleylacetoacetate catalysed by a partially purified extract $(10 \mathrm{mg}$. protein $/ \mathrm{ml})$ of vibrio $O 1$. In $(a)$, cuvettes contained, in a final volume of $3 \mathrm{ml} ., 1 \cdot 0 \mu$ mole homogentisate, distilled water and either $0.2 \mathrm{ml}$. extract, $(\bigcirc-0), 0.1 \mathrm{ml}$. extract $(-0)$, or $) \cdot 05 \mathrm{ml}$. extract $(\triangle-\triangle)$. In $(b)$, the complete system contained in $3 \mathrm{ml}$, $0.06 \mu$ mole 'liver' maleylacetoacetate, $1.0 \mu$ mole GSH, distilled water and either $0.05 \mathrm{ml}$. extract $(\triangle-\triangle)$ or $0.1 \mathrm{ml}$. extract $(\square-\square)$. Similar systems contained 'bacterial' maleylacetoacetate with $0.05 \mathrm{ml}$. extract (-๑) or $0.1 \mathrm{ml}$. extract $(\boldsymbol{\Delta}-\mathbf{\Delta})$. A control cuvette contained maleylacetoacetate and $\mathbf{0} \cdot \mathbf{1} \mathrm{ml}$. of extract but no GSH (O-O).

phosphate + sulphuric acid reagent : $43 \cdot 5 \mathrm{~g} . \mathrm{KH}_{2} \mathrm{PO}_{4}$ and $20 \mathrm{ml} .5 \mathrm{~N}$-orthophosphoric acid were dissolved in $500 \mathrm{ml}$. of $2 \cdot 4 \mathrm{~N}-\mathrm{H}_{2} \mathrm{SO}_{4}$ and diluted to 1 1. with distilled water. Both solutions of maleylacetoacetcte developed a lavender colour which changed slowly to orange (Ravdin \& Crandill, 1951).

\section{Formation and disappearance of maleylacetoacetate catalysed by partially purified cell extracts}

Saturated ammonium sulphate solution, brought to $\mathrm{pH} \mathrm{7 \cdot 3}$ with ammonia, was added dropwise with stirring to a crude extract of cells until $60 \%$ saturated. The precipitate was centrifuged at $10,000 \mathrm{~g}$ for $15 \mathrm{~min}$. at $2^{\circ}$, the supernatant fluid discarded and the pellet dissolved in phosphate buffer. The solution was dialysed against changes of buffer at $5^{\circ}$ ur til the dialysis residue no longer gave a reaction for sulphate ions; then $0.4 \mathrm{ml}$. of $0.033 \mathrm{M}-\mathrm{FeSO}_{4}$ was added to each $10 \mathrm{ml}$. 
of treated cell extract. After incubation for $1 \mathrm{hr}$. at $5^{\circ}$ a slight precipitate was centrifuged down and discarded. In phosphate buffer $(\mathrm{pH} 7 \cdot 2)$ this extract catalysed a linear production with time of maleylacetoacetate; this was followed by measuring the increase in extinction at $330 \mathrm{~m} \mu$, from homogentisate at room temperature (Fig. 4a). The extract also decomposed both 'bacterial' and 'liver' maleylacetoacetate, but only on addition of reduced glutathione (Fig. $4 b$ ).

\section{DISCUSSION}

The work of Ravdin \& Crandall (1951) and Knox \& Edwards (1955) established that the following reactions occur in animal liver:

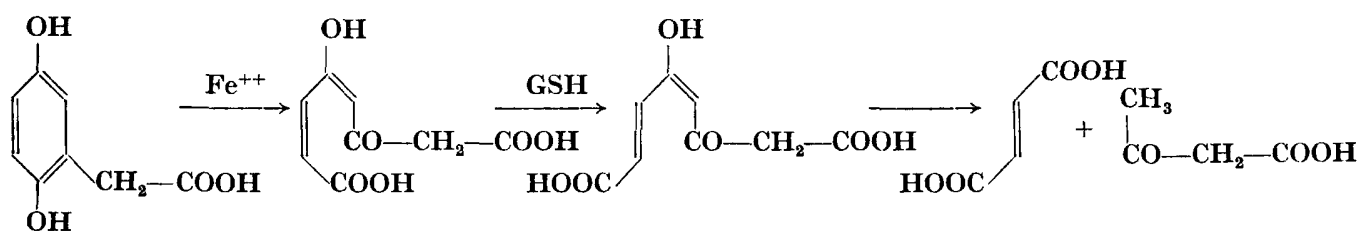

homogentisate $\rightarrow$ maleylacetoacetate $\rightarrow$ fumarylacetoacetate $\rightarrow$ fumarate + acetoacetate

The requirement of homogentisate oxidase for $\mathrm{Fe}^{++}$ions was readily demonstrated by dialysis of extracts of our vibrio O1; Suda \& Takeda (1950) made a similar observation for a tyrosine-grown pseudomonad. By contrast, it was necessary to use inhibitors to show participation of $\mathrm{Fe}^{++}$ions in homogentisate oxidation by the enzyme from liver (Knox \& Edwards, 1955). These ions may be essential for all known aromatic ring-fission enzymes in bacteria (Dagley et al. 1960). Cell-free extracts did not oxidize phenylacetic acid or its monohydroxylated derivatives (Fig. 1); bacterial enzymes which catalyse the introduction of a hydroxyl group into the benzene nucleus are either labile or not readily soluble (Dagley \& Patel, 1957). Homoprotocatechuic acid, an isomer of homogentisic acid, is an intermediate in an alternative pathway of oxidation of phenylacetate (Kunita 1955b) but it was not oxidized in the presence of extracts of our vibrio O1. Homogentisate was oxidized with the uptake of 1.0-1.5 $\mu$ moles $\mathrm{O}_{2} / \mu$ mole substrate; oxygen may be required both for ring-fission and for oxidation of fumarate which is shown as a product of the above reaction sequence. Although it has not been identified as a product, fumarate is readily oxidized by cell-free extracts of the vibrio, with an uptake of $0.5 \mu$ mole $\mathrm{O}_{2} / \mu$ mole substrate.

Further evidence for the above reaction sequence in phenylacetate-grown vibrio $\mathrm{O} 1$ is provided by: (i) the adsorption spectra at various $\mathrm{pH}$ values of the product of homogentisate oxidase (Fig. 2); (ii) the fact that this product gives the same colour reaction with $o$-phenylenediamine as authentic maleylacetoacetate; (iii) the ability of partially-purified extracts to decompose the latter only when incubated with reduced glutathione, the known cofactor of maleylacetoacetate isomerase (Fig. $4 b$ ). Homogentisate was converted almost quantitatively to acetoacetate as predicted by the proposed sequence (Table 1). These reactions were also similar to those studied by Lack (1959), who showed that maleylpyruvate was an intermediate in the oxidation of gentisic acid by bacterial cell extracts. 
P.J.C. is indebted to the Deparment of Scientific and Industrial Research for a Research Studentship.

\section{REFERENCES}

Dagley, S., Evans, W. C. \& Ribbons, D. W. (1960). New pathways in the oxidative metabolism of aromatic compounds by micro-organisms. Nature, Lond. 188, 560.

Dagley, S., Fewster, M. E. \& HAYpold, F. C. (1953). The bacterial oxidation of aromatic compounds. J. gen. Microbiol. 8, 1.

Dagley, S. \& Patel, M. D. (1957). Oxidation of $p$-cresol and related compounds by a Pseudomonas. Biochem. J. 66, 227.

Happold, F. C. \& Key, A. (1932). 'The bacterial purification of gasworks' liquors. The action of the liquors on the bacterial flora of the sewage. J. Hyg., Camb. 32, 573 .

Hughes, D. E. (1951). A press for disrupting bacteria and other micro-organisms. Brit. J. exp. Path. 32, 97.

Jones, J. D., Smith, B. S. W. \& Evans, W. C. (1952). Homogentisic acid as an intermediate in the metabolism of tyrosine by the aromatic ring-splitting micro-organisms. Biochem. J. 51, xi.

King, J. A. \& McMillan, F. H. (1946). Studies on the Willgerodt reaction. IV. The preparation of nuclear-substituted phenylacetic acids and some further extensions of the reaction. J. Amer. chem. Soc. 68, 2335.

Knox, W. E. (1960). In The Enzymes, 2, 253. Ed. P. D. Boyer, H. Lardy \& K. Myrbäck. 2nd ed. New York: Academic Press Inc.

KNox, W. E. \& EDwards, S. W. (1955). The properties of maleylacetoacetate, the initial product of homogentisate oxidation in liver. J. biol. Chem. 216, 489.

Krueger, R. C. (1952). Crystalline acetoacetic acid. J. Amer. chem. Soc. 74, 5536.

Kunita, N. (1955a). Bacterial oxidation of phenylacetic acid. II. The pathway through homogentisic acid. Med. J. Osaka Univ. 6, 703.

Kunita, N. (1955b). Bacterial oxidation of phenylacetic acid. I. The pathway through homoprotocatechuic acid. Med. J. Osaka Univ. 6, 697.

LACK, L. (1959). The enzymic oxidation of gentisic acid. Biochim. biophys. Acta, 34, 117.

Neuberger, A. (1947). Studies on alcaptonuria. I. The estimation of homogentisic acid. Biochem. J. 41, 431.

Ravdin, R. G. \& Crandall, D.I. (1951). The enzymatic conversion of homogentisic acid to 4-fumarylacetoacetic acid. J. biol. Chem. 189, 137.

Rothera, A. C. H. (1908). Note on the sodium nitroprusside reaction for acetone. $J$. Physiol. 37, 491.

Sols, A. (1947). An improved biuret reaction of proteins and the two-standard colorimetry. Nature, Lond., 160, 89.

Suda, M. \& Takeda, Y. (1950). Metabolism of tyrosine. I. Application of successive adaptation of bacteria for the analysis of the enzymic breakdown of tyrosine. J. Biochem. (Japan), 37, 375.

Umbreit, W. W., Burris, R. H. \& Stauffer, J. F. (1949). Manometric Techniques and Tissue Metabolism. Minneapolis, U.S.A.: Burgess Publ. Co.

WALKER, P. G. (1954). A colorimetric method for the estimation of acetoacetate. Biochem. J. 58, 699. 